\title{
A mulher e o cigarro: representações de feminilidade nos anos $1920^{1}$
}

Woman and cigarretes: representations

of womanhood in the $1920{ }^{2}{ }^{2}$

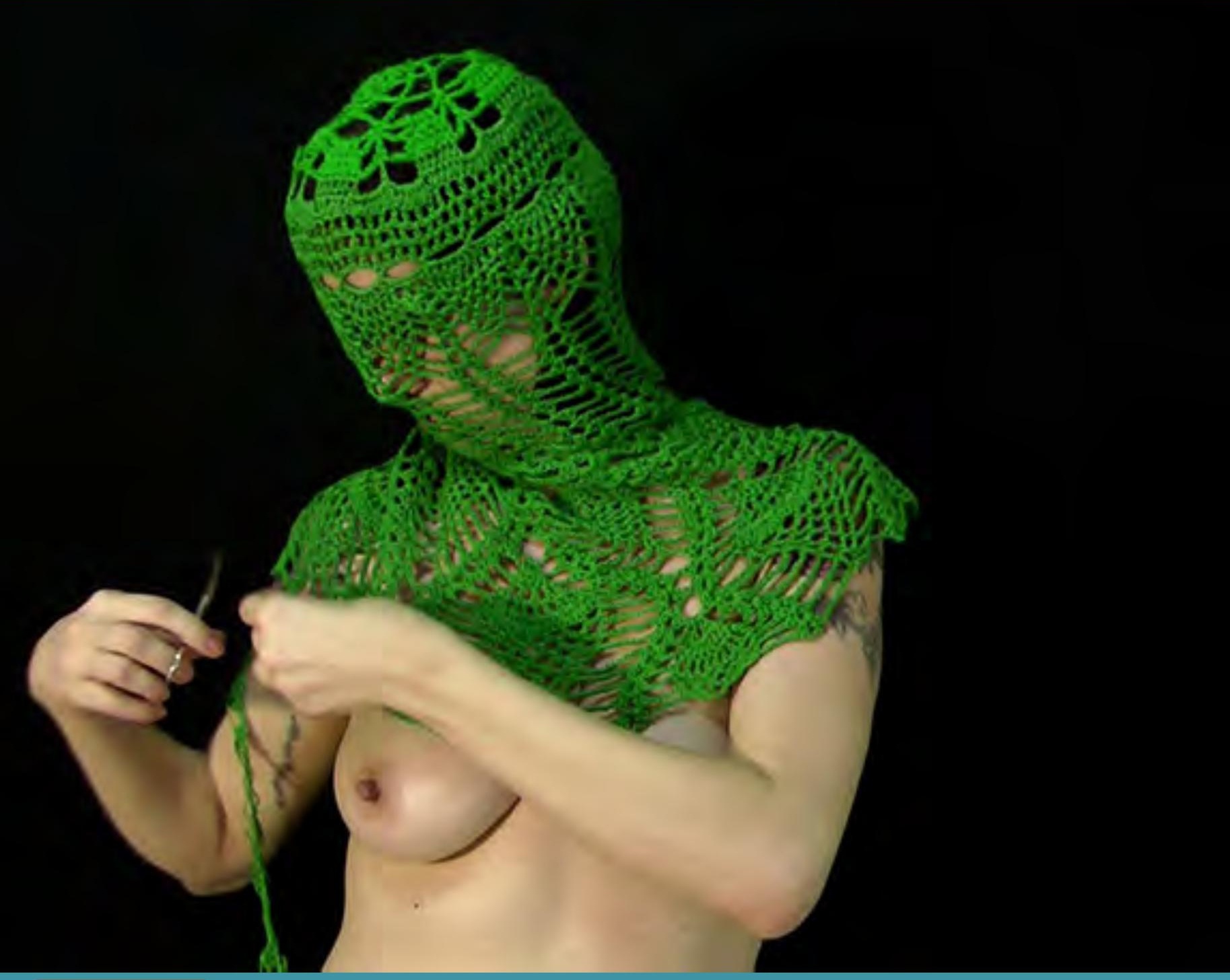

1 Este artigo é uma versão ampliada da comunicação homônima apresentada no Colóquio "Imprensa, Moda e Mulher", que ocorreu na Casa de Rui Barbosa em agosto de 2018.

2 An earlier version of this article was presented at the "Press, Fashion and Women" Seminar held in Rio de Janeiro at Casa de Rui Barbosa in august, 2018. 


\section{Marissa Gorberg ${ }^{3}$}

ORCID: https://orcid.org/0000-0003-2382-6537

[resumo] 0 presente trabalho visa à investigação do hábito tabagista de mulheres no início do século XX, entre as décadas de 1910 e 1920, como prisma privilegiado para vislumbrar formas de elaboração da feminilidade. Sob uma perspectiva da História Cultural, a observação da utilização do cigarro pelas mulheres é capaz de descortinar aspectos importantes do processo de transformação do feminino, evidenciando o balanço entre antigos códigos morais e o desejo de liberdade e a equiparação de gêneros. Em um período de aceleração da vida metropolitana, a disseminação de práticas até então condenadas socialmente provoca reflexões acerca da construção do arquétipo da "mulher moderna" e seu papel social em meio ao incremento do consumo, da industrialização e da comunicação de massa.

[palavras-chave] Tabagismo. Cigarros. Mulher: Gênero. Feminilidade.

[abstract] This study aims to investigate the smoking habit among women at the beginning of the 20th century, especially between 1910 and 1920, as a privileged way of contemplating different forms of building femininity. From a Cultural History perspective, the observation of cigarette usage by women might unveil relevant aspects of women's transformational process inside the society, shedding light on the balance between traditional moral codes and the desire of freedom and gender equality. In the accelerated era of metropolitan life, the spread of habits until then socially condemned rouses a reflection upon the construction of the 'modern women' archetype and its social role amid consumerism, industrialization, and mass media growth.

[keywords] Smoking. Cigarettes. Woman. Gender. Feminity.

Recebido em: 14-01-2019

Aprovado em: 04-07-2019

3 Doutora em História, Política e Bens Culturais pelo CPDOC/FGV. E-mail: Lattes: http://lattes.cnpq.br/8300307368469139. 
No período pós-Primeira Guerra Mundial, houve uma aceleração no processo de metamorfose do feminino. 0 conflito provocara deslocamentos nas demandas diárias, exigindo delas o protagonismo em novas funções; o estilo de vida moderno que emanava de centros metropolitanos de países centrais estimulava novas experimentações e sensibilidades, impulsionado pela comunicação de veículos, como o cinema e as revistas ilustradas; e as lutas femininas por igualdade de direitos se intensificavam, no confronto com velhas hierarquias calcadas em distinções de gênero.

Além desses fatores regularmente enumerados pela historiografia (PERROT, 2007; DEL PRIORE, 2004; SOIHET, 1996; FEIJÃO, 2011), há outro que ajuda a compreender algumas transformações significativas verificadas nas elaborações de gênero naquele momento: a influência da cultura americana. De fato, embora o fenômeno da "americanização" tenha ocorrido de modo inconteste após o término da Segunda Guerra Mundial, no entreguerras, aquele parâmetro cultural inovador passou a disputar reconhecimento com a matriz do "Velho Continente", cujo influxo começara a arrefecer na década pós-belle époque. Findo o primeiro grande embate, houve uma primeira fase de inflexão do crescimento do capitalismo americano no âmbito social e cultural da vida europeia, complexificando as relações entre eixos de poder cultural (ABRAVANEL, 2012).

Entre nós, como uma espécie de "cópia da cópia”, verificou-se uma ampliação de marcos culturais estadunidenses, visíveis nas formas de construção da individualidade, do posicionamento e do procedimento social - e o consequente questionamento deles. Enquanto na Europa havia movimentos críticos a essa influência dos Estados Unidos, no Brasil, a americanização tampouco passou incólume à exegese intelectual que percebia no conjunto de procedimentos difundidos por aquele país - o "americanismo emancipador" ao qual se referia com ironia o escritor Benjamin Costallat (1936, p. 161) ? uma decadência moral e uma degradação social.

Sob influxo daquela cultura, uma série de hábitos e comportamentos inéditos se descortinaram para mulheres que vislumbravam outras formas de se relacionar com os homens e consigo próprias. Por meio de produtos culturais de massa, divulgava-se um modo de ser e de viver que era referência para uma nova geração desejosa de consumir e adotar padrões de comportamento sintonizados com uma noção de modernidade indexada a uma matriz exterior.

A disseminação de regras de conduta inéditas era recebida com entusiasmo por alguns - geralmente os jovens, em sua maioria - e profunda rejeição por outros. A penetração da onda yankee provocava debates, contestações e inclusive um sentimento antiamericano, embora mesmo alguns críticos reconhecessem que a presença daquela cultura fosse um fato consumado (HUGGINS, 2017).

No compasso de mutações vertiginosas que desafiavam padrões de moralidade e arranjos familiares tradicionais, a moda, referenciada à realidade, apresentava alterações formais notáveis. Mas as inovações não se restringiam à construção da aparência, reverberando na maneira de se portar em público ou na intimidade, muitas vezes provocando fissuras no arquétipo de feminilidade considerado ideal por certas esferas.

A ousadia de determinadas posturas corporais, de certas formas de dançar, e a apropriação pelas mulheres de sua força de sedução poderiam não ser exatamente uma chave 
para o combate ao machismo vigente, mas não se pode negar que, ao se permitir o gozo de rituais inéditos, elas tangenciavam as fronteiras de certas convenções sociais, em direção à ampliação de sua liberdade.

Nesse panorama, a possibilidade de fumar cigarros afigurou-se em um prazer inaudito, até então majoritariamente restrito aos homens. Não à toa, naquele período, foi difundida uma série de representações que tratavam da prática inovadora, ancoradas em revistas de variedade de ampla circulação. 0 exame dessas representações, sob uma perspectiva da História Cultural (LE GOFF; NORA, 1988), é capaz de trazer à tona um conjunto de tensões em jogo, sob clivagens de gêneros e gerações, contribuindo para o constructo histórico que visa flagrar aspectos das relações de gênero situados no espaço ao longo do tempo.

0 cigarro aparece, com frequência, associado ao estereótipo consagrado da melindrosa dos anos 1920, tanto na esfera acadêmica (LATHAM, 2000; ZEITZ, 2006; PINHEIRO, 2015) quanto no imaginário popular. Em fantasias de carnaval e trajes temáticos (figuras 1 e 2) que remetem à personagem e ao período, é comum a composição que inclui vestido de franjas tubular adornado por colares de pérolas, plumas, faixa para o cabelo e piteira para o cigarro.

FIGURAS 1 E 2 - ARQUÉTIPOS DE MELINDROSA INCLUEM PITEIRA E CIGARRO
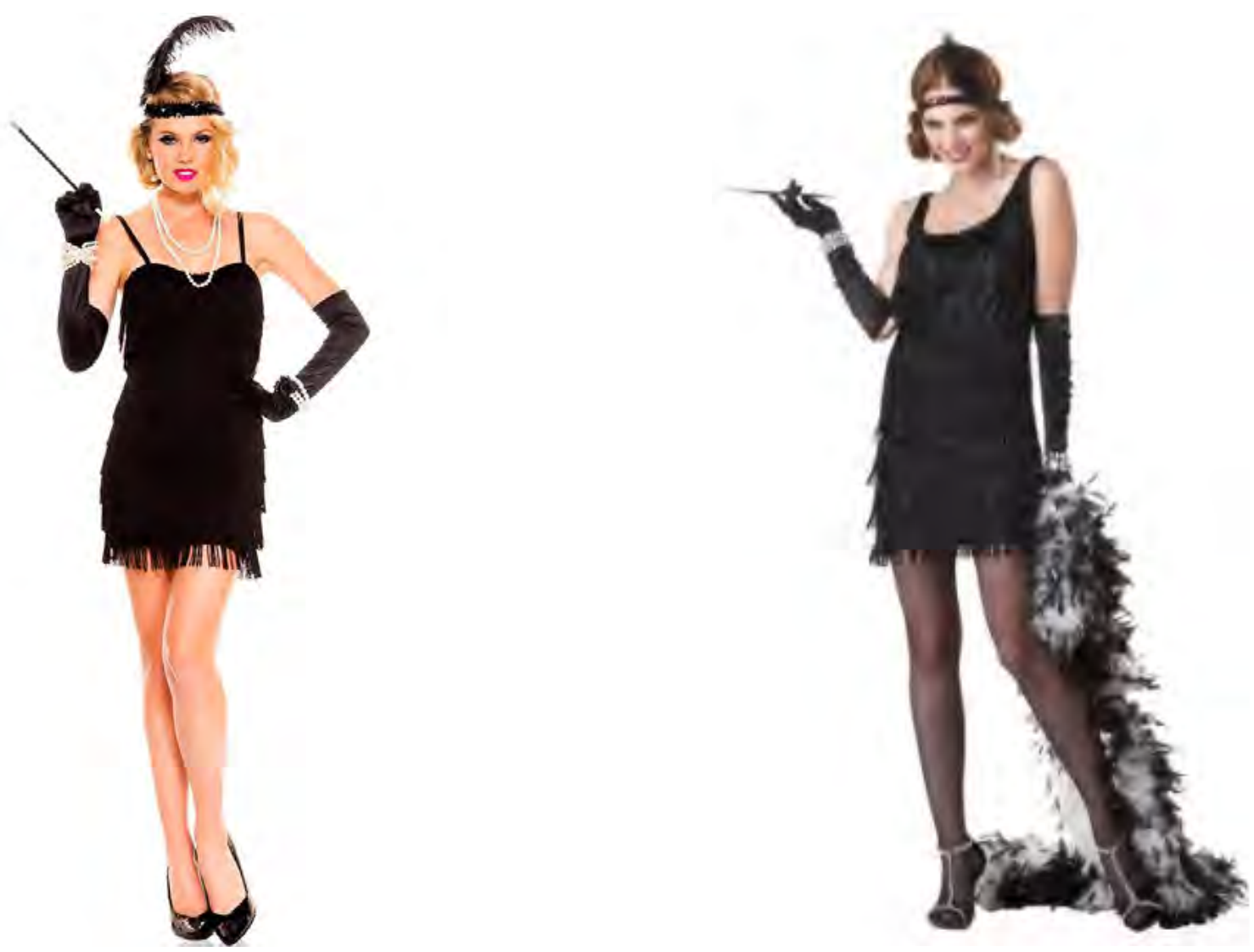

FONTE: www.ebay.co.uk e www.fantasyfantasias.com.br. Acesso em: 14 jul. 2019. Imagens obtidas mediante impressão de tela. 
Investido de significações simbólicas várias, o objeto de fumo incensava - com duplo sentido - padrões de sexualidade então válidos, materializando a chama das disputas de força e poder que perpassavam as elaborações dos gêneros feminino e masculino. Na visão de Beatriz Resende, "a melindrosa é bem a imagem dos anos loucos que se iniciam" e "até o final da década simbolizará um desejo de liberdade, de novidades, de sintonia com o resto do mundo" (RESENDE, 2006, p. 17-18). Uma versão brasileira da flapper americana - termo inglês disseminado em 1915, nos Estados Unidos, pelo jornalista H. L. Mencken na revista The Smart Set para designar "a young and somewhat foolish girl, full of wild surmises and inclined to revolt against the precepts and admonitions of her elders" (ROSS, 2000, p. 61) ou da garçonne francesa, imortalizada por Victor Margueritte no romance de mesmo nome (MARGUERITTE, 1922).

A figura da melindrosa seria a perfeita tradução do espírito daquela década: uma mulher elegante, desinibida sexualmente, desafiadora de códigos morais, com acesso ao trabalho, lançadora de modismos, interessada em festas, filmes, flertes, roupas, drinques, automóveis, cigarros e uma série de diversões e possibilidades que iam de encontro à provável austeridade de seus pais; a própria tradução da sedução e da esfuziante inconsequência identificada com aqueles anos. Juntamente com seu "par" masculino, o almofadinha, eles seriam o epíteto da diluição de parâmetros outrora vigentes nas atribuições de identidades, perceptíveis na elaboração estética de seu visual e nos valores perpetrados em sua forma de viver.

0 arquétipo feminino capaz de provocar admiração em uns, evocava outrossim uma série de preconceitos em outros, evidentes na forma como a mídia impressa e parte da produção literária se referiam a essa mulher: "Uma jovem de 'cabecinha oca', uma bonequinha de salão, alegre e brilhante, insuperável em 'flirts', mas com a intelectualidade nula" (BEIRA-MAR, 1927, p. 12). A forma como a personagem era retratada acentuava, muitas vezes, aspectos frívolos a ela atribuídos - um exagerado interesse por moda, consumo, sedução - em detrimento de predicados nobres.

Entre tantas provocações comportamentais associadas ao proceder feminino libertário da época, o hábito de fumar, pelas mulheres, chama a atenção pelas consideráveis alterações que sofreu em sua percepção.

Historicamente, o uso de charutos, cachimbos e cigarros, sobretudo a partir do início do século XX, era prerrogativa dos homens; o hábito era desaprovado, socialmente, às mulheres (WALDRON, 1991). Com efeito, de acordo com o relato encontrado na série American popular culture through history:

Antes de 1920, as mulheres que fumassem em público eram consideradas prostitutas, boêmias ou intelectuais de vanguarda. Mas após a Primeira Guerra Mundial, até mesmo mulheres respeitáveis de classe média começaram a tragar cigarros, como um sinal de sua equiparação com os homens e de sua emancipação dos códigos vitorianos de conduta. (DROWNE; HUBER, 2004, p. 41) ${ }^{4}$

\footnotetext{
4 Tradução nossa para: "Prior do 1920, women who smoked publicly were usually believed to be prostitutes, bohemian, or avant-garde intellectuals. But after World War I, even respectable middle-class women began puffing on cigarretes as a public display of both their equality with men and their emancipation from Victorian codes of behavior".
} 
Havia uma conexão entre moralidade e fumo, ou seja, "boas meninas" não fumavam, até que o cigarro começou a ser usado por elas independentemente das possíveis associações àquele gesto, ou talvez precisamente por causa delas — ou seja, fumar poderia ser um artifício de sedução, um símbolo de rebelião juvenil, emancipação feminina e equiparação dos sexos.

A aceitação do uso do cigarro pelas mulheres, ao menos nas grandes cidades, é apontada por autores americanos como forte indicador de uma verdadeira revolução motivada pela busca de igualdade de gêneros. Na esfera privada, por exemplo, era comum haver uma separação entre homens e mulheres após o jantar para que eles fumassem em particular (e possivelmente tratassem de assuntos interditos a elas). Com a adoção da prática pelas mulheres, elas passaram a fumar os mesmos cigarros e portavam seus cinzeiros sala adentro, "invadindo" um território masculino (ALLEN, 2000).

A revista americana Vogue, na edição de 15 de dezembro de 1916, sinalizava explicitamente as novas tendências do tabagismo feminino. Na matéria intitulada My lady's nicotine, dedicada especialmente ao tema, a publicação claramente denotava uma mudança de padrões e chancelava a publicidade do hábito.

Iniciado por um breve retrospecto, o artigo frisava que, não havia muito tempo, o fato de uma mulher acender um cigarro em um salão público causaria espanto e provocaria julgamentos negativos; aquela que o fizesse seria considerada provavelmente uma "atriz". A revista observava então um ponto de virada em função da decisão do Hotel Ritz-Carlton de permitir, em suas dependências, que as mulheres fumassem:

E então o Hotel Ritz-Carlton abriu suas respeitáveis portas, decidiu que as mulheres também eram gente e deixaram claro, óbvio, que nenhuma mulher precisaria abrir mão do seu cigarro quando ela entrasse em qualquer um de seus restaurantes. Outros hoteis respeitáveis rapidamente seguiram o exemplo - e agora há menos espanto em ver uma mulher fumar em público do que vê-la usando um finger-bowl ${ }^{5}$. (VOGUE, 1916, p. 61) 6

A forte ironia que perpassa a narrativa do periódico engendra múltiplos entendimentos das questões suscitadas. Ao passo que parece comemorar a introdução de novos hábitos promovidos pelo hotel e sua decorrente incorporação no tecido social, a verve de Vogue faz pensar no machismo existente - a mulher, voilà, fora considerada "gente" - e nas barreiras tradicionais que se contrapunham às inovações comportamentais. Se uma mulher fumando em público seria tão comum quanto uma mulher usando um finger-bowl, a comparação deixa dúvidas sobre a real capacidade de aceitação - afinal, ambas as práticas seriam bastante controversas ou, no mínimo, uma exclusividade de esferas mais elitistas.

\footnotetext{
Os finger-bowls ou "tigelas de dedo" eram recipientes com água oferecidos em restaurantes de luxo no fim das refeições para que as mulheres limpassem os dedos. Um item controverso, ora associado à exclusividade do estabelecimento, ora ridicularizado pelas classes mais populares, contestado por questões de higiene, ostentação e desperdício, que caiu em desuso na terceira década do século XX.

${ }^{6}$ Tradução nossa para: "And then the Ritz-Carlton hotel opened its hospitable doors, decided that women were people, and let it be known, quite as a matter of course, that no women need leave her cigarette behind when she entered any of its restaurants. Other smart hotels quickly followed its example - and now there is no more thrill in seeing a women smoke in public than there is seeing her use her finger-bowl".
} 
A publicação era prodigiosa na construção simbólica do ato de fumar pelas mulheres, considerado a um só tempo uma conquista, uma virtude, uma vantagem e uma responsabilidade. Só deveriam fazê-lo em público aquelas que dominassem a arte do manuseio, do gestual, da escolha do aroma; para elas, o fumo seria uma arma a mais no seu arsenal de sedução e um motivo a mais para o desejo de consumir.

Nesse sentido, a matéria apresentava uma série de objetos, como caixas esmaltadas, piteiras adornadas com ouro e prata, cinzeiros e acendedores - a maioria produzida por fabricantes famosos, como Cartier. 0 que não causa espécie, visto que a revista era uma plataforma de divulgação de tendências de moda e artefatos da esfera material voltada para classes mais altas interessadas em elementos de distinção social.

Alguns anos mais tarde, em 1923, a revista inglesa Punch oferecia uma representação gráfico-satírica das transformações que envolviam o ato de fumar e as dinâmicas de gênero; um homem hesitante pergunta às mulheres presentes no recinto se elas se importam que ele fume: "Excuse me, but do any of you ladies object to smoking?" (Com licença, alguma das senhoritas se opõe ao fumo?). 0 anacronismo da pergunta é evidente, pois, na cena, todas elas fumam (figura 3).

FIGURA 3 - ELAS AGORA TAMBÉM FUMAM

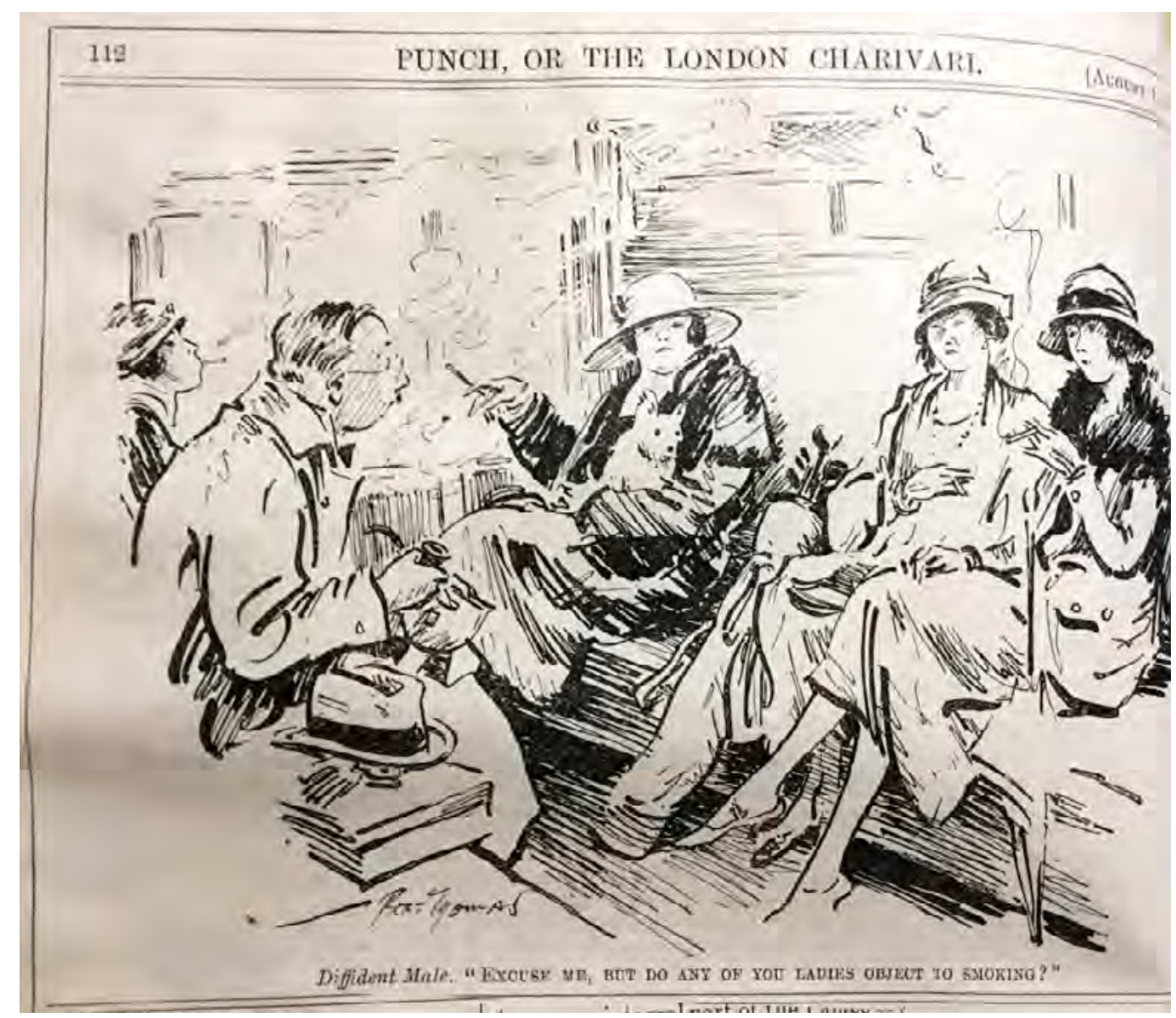

FONTE: Revista Punch n. 4282, 1ํ de agosto de 1923. Acervo British Library. 
A charge de Bert Thomas deflagra alterações nas relações de gênero evidenciadas por meio da utilização do cigarro. Explique-se: não havia muito tempo, era franqueada apenas aos homens a fruição comunal do tabaco. Em ocasiões sociais, a "boa educação" recomendava àqueles que fossem fumar que pedissem licença às mulheres para fazê-lo, mas isso não significava uma submissão masculina, do contrário, os homens apenas encontravam formas convencionalmente adequadas de gozar um prazer exclusivo; muitas vezes, inclusive, eles se retiravam para outros ambientes, reunidos à parte das mulheres.

Na representação da Punch acima há uma clara troca de papéis: o homem é descrito como um personagem tímido, vacilante (diffident male) e aparece como minoria entre elas; as mulheres, por sua vez, olham com semblante assertivo e confiante, enquanto fumam ostensivamente. É como se, pela fruição do cigarro, houvesse uma inversão no lugar, na maneira de agir e no balanço de forças entre homens e mulheres.

Enquanto a Vogue e a Punch retratavam, a seu modo, os ventos da mudança, em 1924, a revista carioca Frou-Frou publicou "O Cigarro e as Mulheres", um artigo que versava sobre o tema em terras nacionais:

O cigarro era, até bem pouco tempo, depois do cão, o mais fiel amigo do homem... Hoje, com a evolução e concorrência do feminismo, a mulher elegante e emancipada deste século do avião e da morfina, fez do primeiro um objeto de luxo e do segundo a sua mais refinada distração.

O cigarro fino e aromático, de fumo loiro, preso aos lábios rubros de uma Eva esguia e nervosa, dá à silhueta das melindrosas do nosso tempo um ar de petulância e irreverência, algo de encanto e de malícia.

Os nossos avós, severos e caturras, ficariam escandalizados se pudessem assistir a essa desenvoltura hodierna, que, de certo modo, é uma espécie de bolchevismo de boudoir...

Que mal faz que as mulheres o usem, se com esse hábito um tanto revolucionário aumentam o prestígio de sua graça?

Tudo se perdoa em uma mulher... bonita.

Se elas já invadiram, triunfalmente, a esfera de atividade até agora privilégio odioso e retrógrado de Adão, concorrendo, na atualidade, com vantagem, e, por vezes, superando o sexo monopolizador de ontem, é justo e razoável que também adotem os seus hábitos e os seus gestos. As elegantes já não se servem da cartolinha, da bengala flexível, dos óculos à Harold Lloyd, enfim, não chegaram até a revolta capilar da cabeleira à la garçonne?

O cigarro, portanto, não lhes pode ficar mal. Depois, não se compreenderia que elas o dispensassem, quando já as vemos, nesta linda cidade, trabalhando nas repartições públicas e nos escritórios e até nas academias, e, no estrangeiro, como embaixadoras, ministras de Estado e até como policiais. 


\title{
$[\cdots]$
}

Não lhes perdoaríamos, se ousassem profanar a boca rosa com a insolente desproporção de um charuto, mesmo que fosse um havana legítimo. 0 cigarro, sim, é um capricho que as torna mais graciosas e tentadoras.

Mas, imaginamos, com horror, se um dia, por um excesso de feminismo, ou melhor, de imitação dos vícios tolerados dos homens, chegassem a fumar... cachimbo! (FROU-FROU, 1924, p. 23)

Assim como o artigo citado da revista americana Vogue, o texto da Frou-Frou é iniciado por um preâmbulo norteador do tabagismo em tempos passados, de modo a deixar claro que havia uma modificação entre hábitos de "ontem" e "hoje". Há uma comparação entre o cigarro e o cão, que seriam, em outras eras, intrínsecos ao universo masculino (os "melhores amigos" do homem), mas, na modernidade dos anos 1920, passavam a integrar o repertório feminino - o cigarro como "objeto de luxo" e os cães como sua "mais refinada distração".

A comparação tinha sua razão de ser: tanto o cigarro quanto os cachorros eram novidades na rotina das mulheres, algo até então incomum nos lares burgueses. 0 interesse pela criação de cães domésticos por elas aumentou paralelamente à inauguração, em 10 de novembro de 1922, do Brasil Kennel Club do Rio de Janeiro, uma sociedade civil privada que promovia concursos e exposições de cães de raça frequentados pela alta sociedade e que eram registrados na imprensa (GORBERG, 2018).

Os homens, por sua vez, percebiam o apreço canino com desconfiança, estranheza e quiçá, ciúme. Alguns formadores de opinião renomados à época, como o cartunista Belmonte, os escritores Benjamin Costallat e Olegário Mariano, manifestaram-se sobre o tema, não sem entrever certa condenação. Reproduzimos, a seguir um trecho de Mariano:

\author{
Extravagâncias \\ Têm as mulheres de agora \\ Manias originais \\ Uma, a que mais me apavora, \\ É o amor pelos animais. \\ Muitas damas eu conheço \\ Que educam gatos e cães \\ Com um tal gosto, um tal apreço \\ Como se fossem as mães \\ Quem não tem filhos, procura \\ Ter bichos. É natural... \\ Mas viver uma criatura \\ Beijando cães? É imoral. (MARIANO, 1927, p. 29)
}

Julgamos relevante contextualizar a relação entre mulheres e cachorros domésticos naquele período uma vez que ela foi utilizada - juntamente com o cigarro - como índice da "evolução e concorrência" do feminismo pelo artigo da revista Frou-Frou. Os dois exemplos 
- cachorros e cigarros - delineavam a "mulher emancipada" que adotava tais "hábitos revolucionários", impensáveis para gerações anteriores.

É forçoso observar, contudo, que embora a revista parecesse favorável aos sopros da mudança, reforçava certos papeis e estereótipos de gênero e de classe. 0 cigarro seria aceito pois exacerbava o poder de atração da "mulher elegante", aumentaria o "prestígio de sua graça", mas às mulheres caberiam funções de beleza ("tudo se perdoa em uma mulher... bonita") e magreza (Eva esguia) em conformidade com padrões estéticos definidos.

O editorial lamentava o "privilégio odioso e retrógrado" do campo de ação masculino e celebrava a "invasão" feminina no mercado de trabalho. A busca da equiparação funcional estaria associada à adoção de hábitos e gestos até então exclusivamente masculinos, visíveis na construção da aparência, no vestuário e nos movimentos corporais. Lembre-se que nos anos 1920 a androginia foi tendência na moda, e as mulheres passaram a usar itens do guarda-roupa deles (cartolas, bengalas) com cabelos bem curtos, muitas vezes com vestidos tubulares soltos sobre seios contidos (FEIJÃO, 2015).

Mas a conclusão do texto termina por impor um limite ao feminismo, que poderia "pecar por excesso", caso as mulheres resolvessem também fumar cachimbo; o desejo de equivalência de direitos e de liberdade de expressão esbarrava em ideais preestabelecidos para identidades de gêneros, presentes na sociedade que se queria moderna, mas era permeada por fortes marcas de tradição.

As mudanças comportamentais transpassadas pelo uso feminino do cigarro que motivaram um artigo específico na Frou-Frou sobre o assunto consubstanciavam um processo inscrito no decurso da modernidade urbana, catapultada no raiar do século passado. Em uma era em que o "novo" era valorizado e desejado por grupos sociais identificados com certos referenciais de civilização e progresso, a presença cada vez mais ampliada de veículos de comunicação de massa contribuía para disseminar novas formas de ação aliadas a repertórios simbólicos capazes de atingir camadas profundas de sensibilidade.

Conquanto o cinema tenha exercido um papel preponderante na divulgação de personagens femininas fumantes, a publicidade especializada também cumpriu parte importante nesse itinerário. Ao encontro dos novos rumos do proceder feminino, a indústria tabagista passou a incentivar a utilização do cigarro pelas mulheres, afinal, ao chancelar o uso daquele objeto por elas, descortinava um potencial mercado consumidor, favorável à crescente expansão do setor.

A observação da campanha divulgada em mídia impressa pelos Cigarros Veado ${ }^{7}$ é capaz de auxiliar na compreensão do fenômeno. Em 1915, a marca anunciou na revista Careta suas novas variantes, "semilla", "vanille", "royal" e "sport", cada uma delas representada por uma imagem fotográfica de mulher fumante. No primeiro reclame, as personagens retratadas apresentavam, a um só tempo, uma ideia de sensualidade enunciada no decote, no sorriso e no olhar oblíquo; todas aparecem emolduradas por uma aura de feminilidade inscrita nas flores que seguravam - mediadoras do flerte, símbolo do cortejar masculino (figura 4).

\footnotetext{
Os cigarros Veado eram bastante conhecidos na década de 1910 nas maiores cidades brasileiras. Produzidos pela Imperial Estabelecimento de Fumo, criada pelo português José Francisco Correa em 1876, eram anunciados com frequência na mídia impressa, em periódicos como Careta, Fon-Fon e Eu Sei Tudo, entre outros. A fábrica é apontada como pioneira na indústria tabagista nacional (ARAÚJ0, 2006).
} 


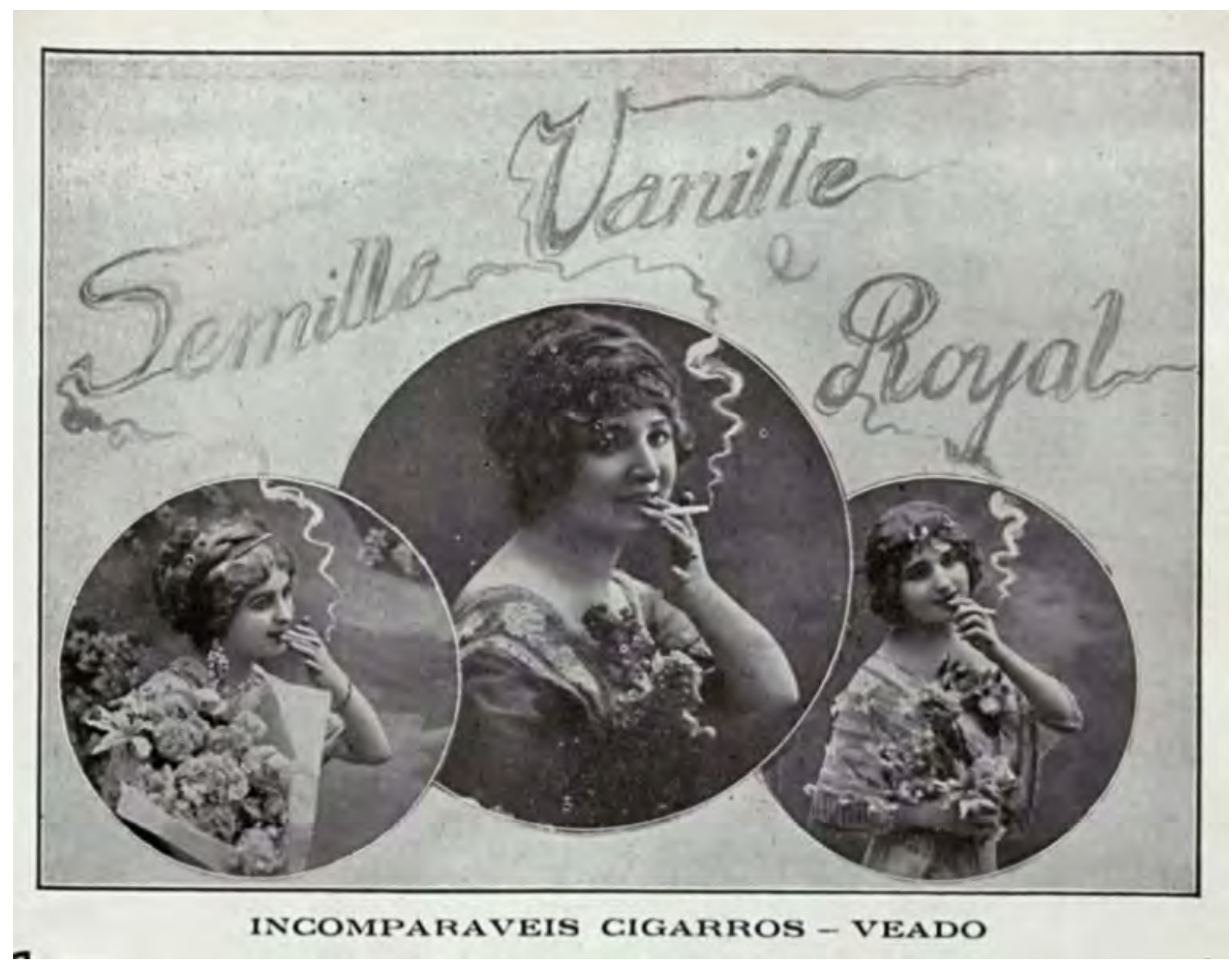

FONTE: Revista Careta, n. 373, 7 de agosto de 1915. Acervo particular.

Aquela marca publicou na mesma revista, no mês seguinte, outro anúncio no qual as mulheres olham diretamente para o leitor com postura desafiadora. Não parecem corresponder à ideia então em voga da "boa moça" recatada e do lar, dependente do pai ou do marido, cujo pudor seria apreciado. Do contrário, surgem vestidas com robe de chambre (à esquerda) e vestido ousado (à direita), com brilhos, transparência e adornos de melindrosa (figura 5), poderiam ser atrizes ou "moças de vida fácil". E mesmo a mulher com costume tailleur (ao centro) se insurge em postura nada convencional para um retrato "de família" ao encarar o olhar com mão na cintura e cigarro na boca. 
FIGURA 5 - CIGARROS ASSOCIADOS A MULHERES “MALCOMPORTADAS”

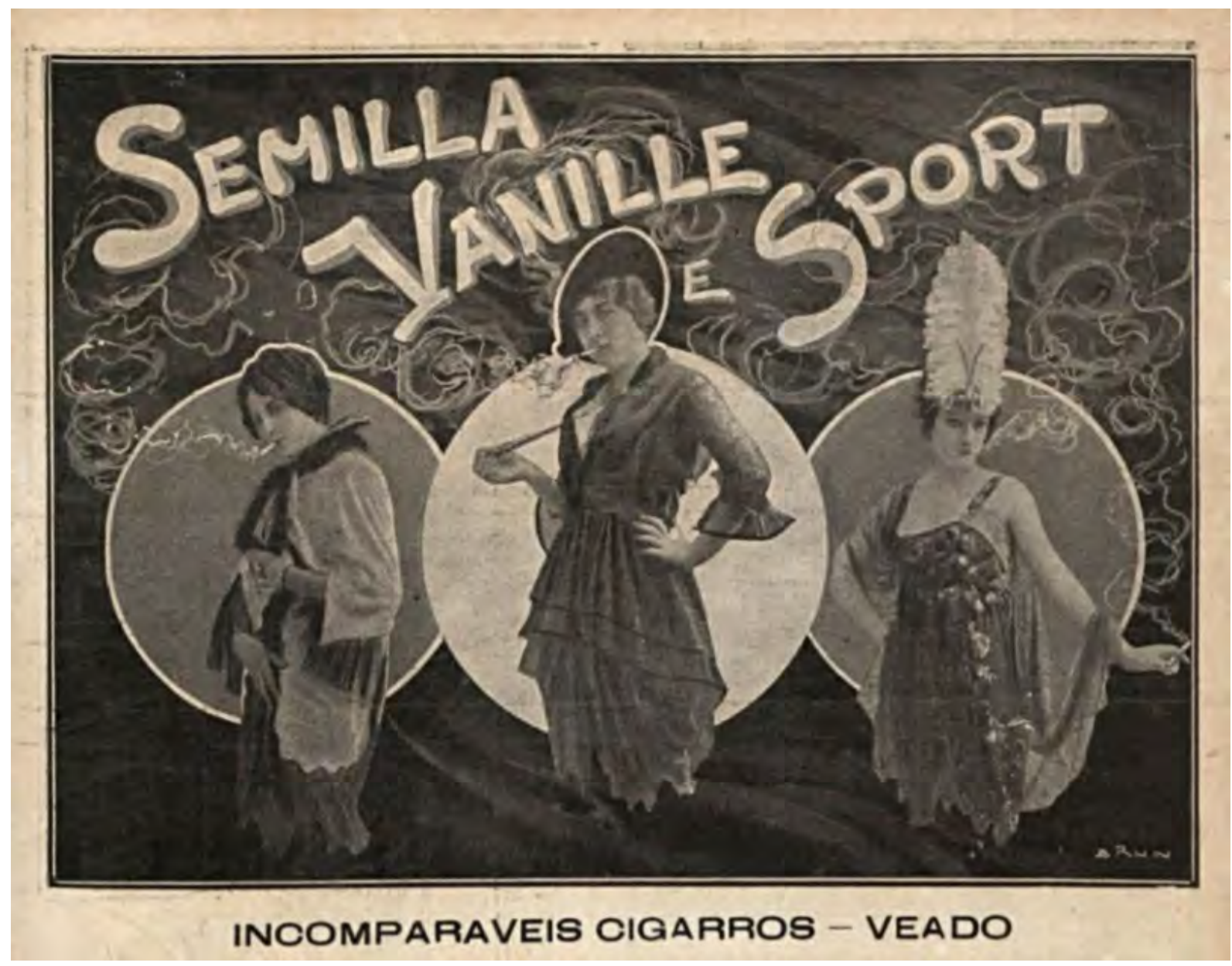

FONTE: Revista Careta, n. 38, 18 de setembro de 1915. Acervo particular.

Éprovável que, naquelemomento, o público-alvo dos anúncios fosse majoritariamente masculino. Nesse sentido, as mulheres que personalizavam os sabores tabagistas reforçariam uma noção machista de que elas seriam "saborosas" e os homens poderiam "tragá-las". 0 fumo aparecia associado a anseios sexuais masculinos; as mulheres retratadas nas propagandas de cigarro - ousadas e "liberais" para os padrões morais da época - contribuiriam para excitar estímulos e incendiar desejos daqueles que eram os consumidores preponderantes dos cigarros.

Decerto que esse viés não pode ser descartado, contudo, não se deve ignorar a atuação simbólica da imagem publicitária que introduzia, em uma das principais publicações do país, o ato de fumar protagonizado por mulheres.

Nos anos seguintes, os anúncios do mesmo fabricante estenderam seu alcance material com o aumento da frequência e do sortimento de veículos nos quais eram impressos, além da Careta, estavam também no almanaque Eu Sei Tudo e na Revista da Semana, por exemplo. Nesta última, passaram a ocupar quinzenalmente a última página inteira, em cores, periodicidade que se manteve nos anos subsequentes. 
O espectro simbólico da sua campanha de "marketing" também foi amplificado; percebemos a inclusão da mulher com maior frequência, delineada em outro tipo de representação, e a incorporação de novos personagens fumantes. Havia, por exemplo, anúncios de cigarros do fabricante Veado cujo protagonista era um Papai Noel (figura 6), outro em que o bispo da igreja católica recomendava ao "rebanho espiritual" que fumassem cigarros York (Revista da Semana, n. 6, novembro de 1917), ainda propagandas nas quais um menino isso mesmo - era retratado fumando "o cigarro do papae" (figura 7). Algo impensável sob a cartilha contemporânea politicamente correta, sob vigilância do Conar.

\section{FIGURAS 6 E 7 - PAPAI NOEL E CRIANÇAS COMO ANUNCIANTES DE CIGARRO}

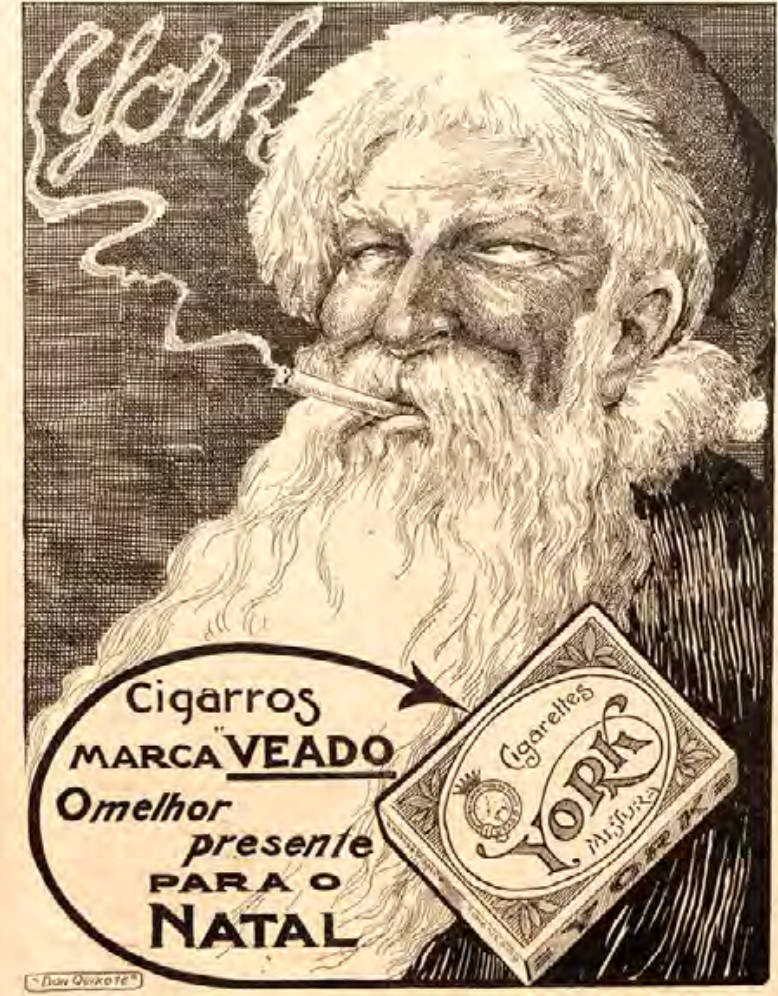

FONTE: Revista D. Quixote, n. 85, dezembro de 1918. Acervo particular.

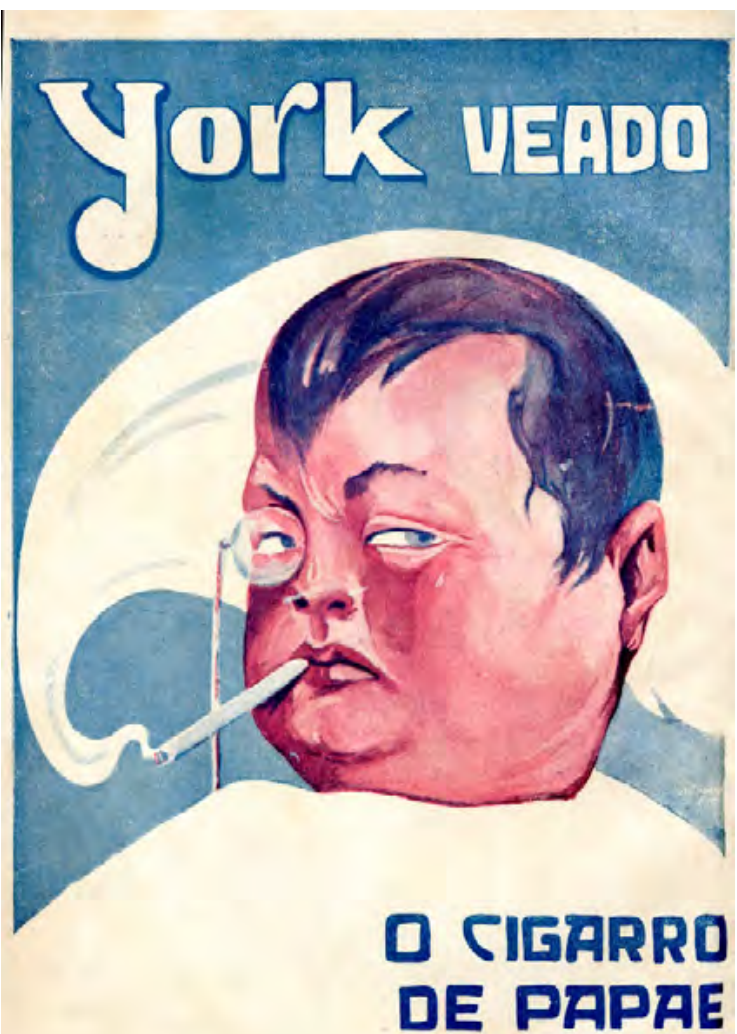

FONTE: Revista Eu Sei Tudo, n. 12, maio de 1918. Acervo particular.

O exame detalhado das representações que contemplavam esses diversos atores publicitários escapa ao escopo primordial deste artigo. Nossa atenção está voltada à mulher, à forma como era retratada e às implicações do seu ato de fumar sob determinadas coordenadas socio-históricas.

Percebe-se, em meados dos anos 1910, um ponto de virada na campanha dos cigarros Veado. Graficamente, os anúncios passaram a incorporar o recurso da cor, até então raramente encontrado nas páginas das revistas ilustradas brasileiras. 0 fato de serem impressos quinzenalmente na última capa da Revista da Semana, com papel de gramatura mais pesada, 
sem dúvida consolidava a marca junto ao público-alvo da renomada revista, formado naquele momento, sobretudo, por camadas sociais mais altas e com grande atuação entre as mulheres.

Lembre-se que, em 1915, a Revista da Semana - que até então pertencia ao Jornal do Brasil - foi comprada pela Companhia Editora Americana e recebeu aporte de equipamentos modernos de impressão. Sob a direção de Carlos Malheiros Dias, incorporou inovações gráficas e abriu mais espaço para o humor, a moda, as artes e a literatura, tornando-se mais "elegante e feminina” (SODRÉ, 1999). A revista aumentava seu poder de atração tanto pelo aspecto físico - plena de ilustrações e fotografias - quanto pelo conteúdo mais leve e diversificado, que agradava em cheio ao público feminino. Colunas sociais, matérias de etiquetas e seções como o "Jornal das Famílias" e o "Consultório da Mulher" reforçavam o apelo da publicação entre as "moças de boa família" interessadas em referenciais de comportamento que abordavam cuidados com a aparência, a família e o lar.

E foi na última capa dessa importante publicação do início do século XX que a mulher se viu retratada como fumante (figura 8), sem que isso implicasse necessariamente um julgamento social de aspecto negativo.

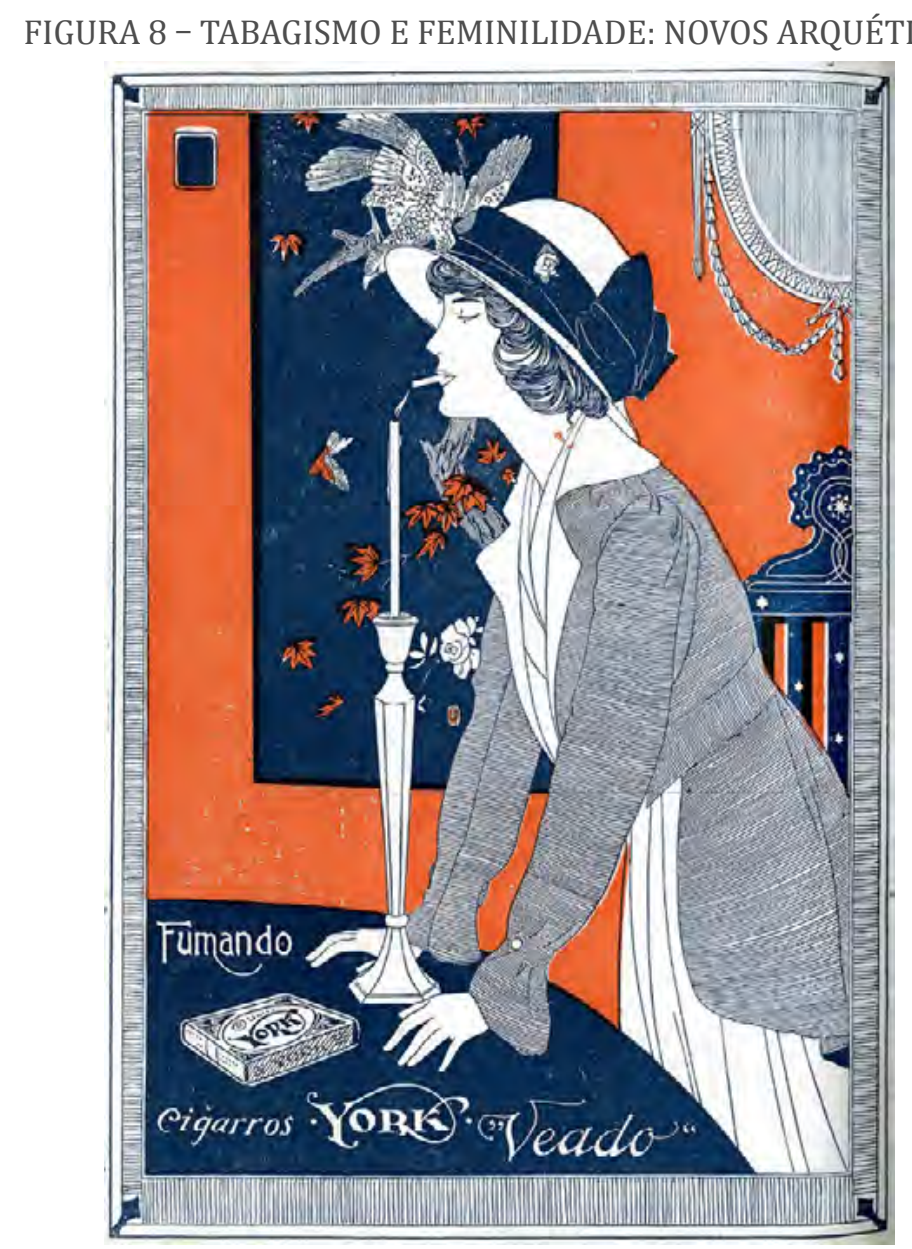

FONTE: Revista da Semana, n. 36, 13 de outubro de 1917. Acervo particular. 
Na imagem, observamos uma moça que acende o cigarro entre os lábios diretamente na chama da vela sobre a mesa. A indumentária e a ambientação remetem a uma atmosfera de alta sociedade; a moça usa chapéu adornado por fita, vestido com comprimento e decote comportados, sob uma espécie de jaqueta redingote com mangas levemente bufantes e babado discreto nos punhos fechados com um botão. 0 ambiente se destaca pelo uso da cor vibrante ao fundo, onde sobressaem uma imagem decorativa oriental, um espelho e um espaldar adornado, a mesa e o castiçal de linhas retas evocam linhas mais limpas que marcariam o estilo art-déco predominante nas décadas seguintes.

Aqui, a mulher fumante não parece ser uma prostituta e sim uma moça moderna, jovem, segura e independente. Com postura inclinada para a frente, debruçada sobre a mesa, ela se apoia com as mãos em gesto firme, porém delicado, e parece prescindir da figura masculina, ao menos para acender seu cigarro.

Paulatinamente, a publicidade externava uma ideia do fumo como prática moderna, elegante e exclusiva, recomendável àqueles e àquelas em busca de novidades, atentos a códigos representativos de status e avanços progressistas. Os cigarros Veado construíam uma imagem de produto "chic" e "de luxo", que poderia - e deveria - ser usufruído por homens e mulheres sem que isso ferisse as "boas normas" sociais (figura 9), do contrário, passava a ser uma atividade afiliada à composição de um modus vivendi requintado.

\section{FIGURA 9 - A PUBLICIDADE DO FUMO COMO PRAZER CONJUNTO}

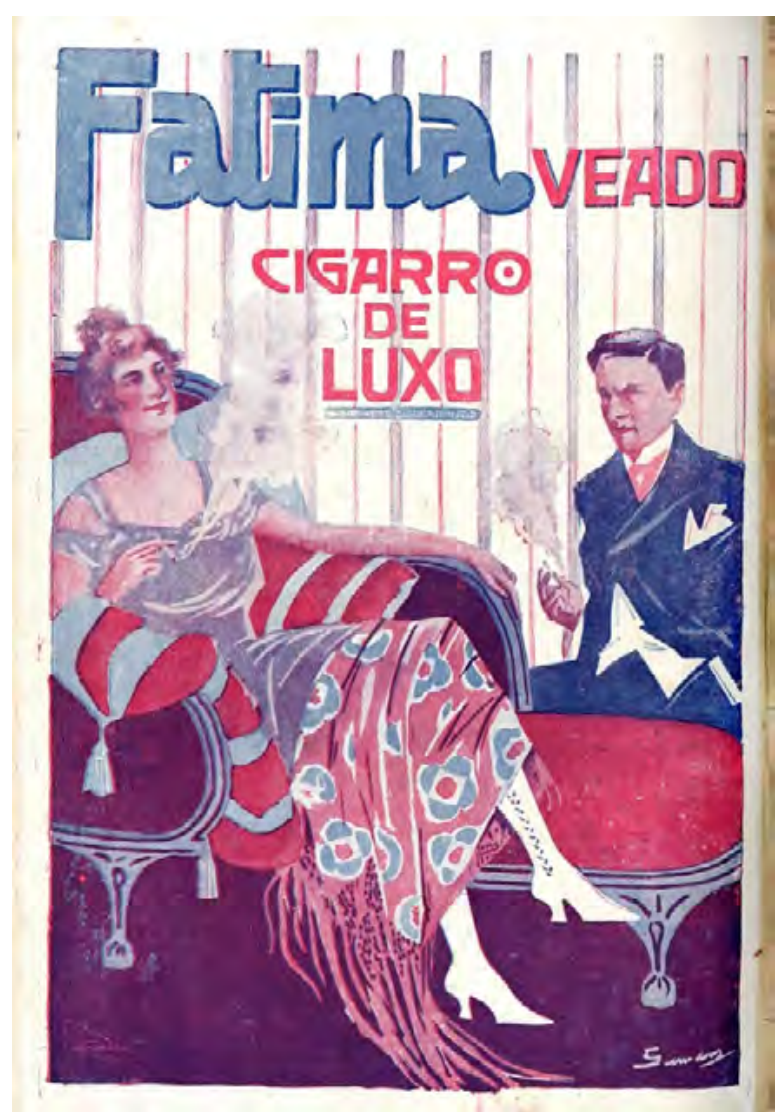

FONTE: Revista da Semana, n. 28, 17 de agosto de 1918. Acervo particular. 
Na situação retratada, a mulher fuma recostada em uma chaise longue de linhas art nouveau em companhia de um homem sentado próximo a ela; parecem gozar daquele prazer relaxadamente, enquanto mantêm a atenção um sobre o outro. Embora não se deva abandonar a possibilidade de uma cena de boudoir, as vestes e a decoração fazem pensar em um ambiente de alto padrão, que poderia ser um clube, um teatro ou um salão de festa particular. Ela está com vestido de festa elaborado, provavelmente de seda ou veludo, colo e braços à mostra, pernas e tornozelos ocultos sob a saia estampada com franjas e botinas de inspiração vitoriana. No anúncio, o cigarro parecia estar alistado entre as prerrogativas femininas usufruídas em público, talvez até mesmo como um pretexto para a interlocução com o sexo masculino.

Em outra representação, no ano seguinte, a mulher reaparece fumando sozinha (figura 10). Vestida conforme os padrões de distinção então em voga - vestido tailleur com gola e botões contrastantes, acessórios vistosos (chapéu de aba larga enfeitado com pena, colar, bois de pele, luvas e sombrinha) -, ela fuma ostensivamente, com o cigarro entre os dedos levantados, e não disfarça a satisfação que tem com isso; olha o objeto e sorri. 0 cigarro La Reine (A Rainha) era apresentado como um produto que faria parte do rol de objetos e ritos da mulher refinada, um emblema "chic" de sua condição de status material e simbólico.

\section{FIGURA 10 - MENSAGEM TABAGISTA PARA MULHERES “ELEGANTES”}

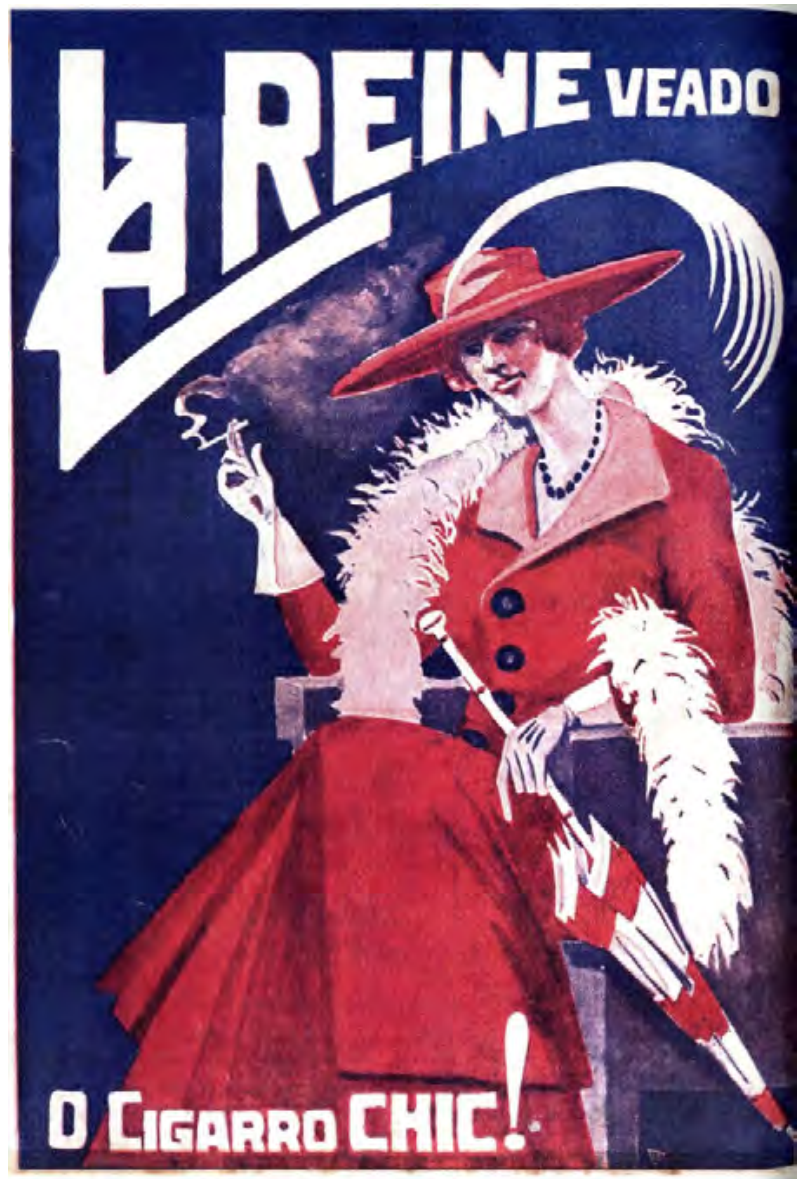

FONTE: Revista da Semana, n. 28, 6 de agosto de 1919. Acervo particular. 
A mudança da identidade visual dos anúncios saltava aos olhos nas ilustrações elaboradas por artistas gráficos que imprimiam muitas vezes suas iniciais no canto inferior direito; as imagens eram compostas em máquinas monotipo nas oficinas gráficas Aureliano Machado \& Co., conforme descrição encontrada no rodapé dos próprios anúncios. A tipografia chamava a atenção pelas linhas limpas, sem serifa, peso variável, desenhadas de modo ousado no espaço, dispostas com recursos de justaposição e realçadas por recursos exclamativos. Fato é que a campanha publicitária se afigurava bastante inovadora a sua época, ratificando a imagem da mulher fumante como sinal de novos tempos muito vibrantes e modernos.

0 próprio processo de incorporação do hábito feminino no tecido social era retratado pela publicidade, como na representação caricatural intitulada "Sol Lucet Omnibus" (figura 11).

\section{FIGURA 11 - O SOL NASCE PARA TODOS}

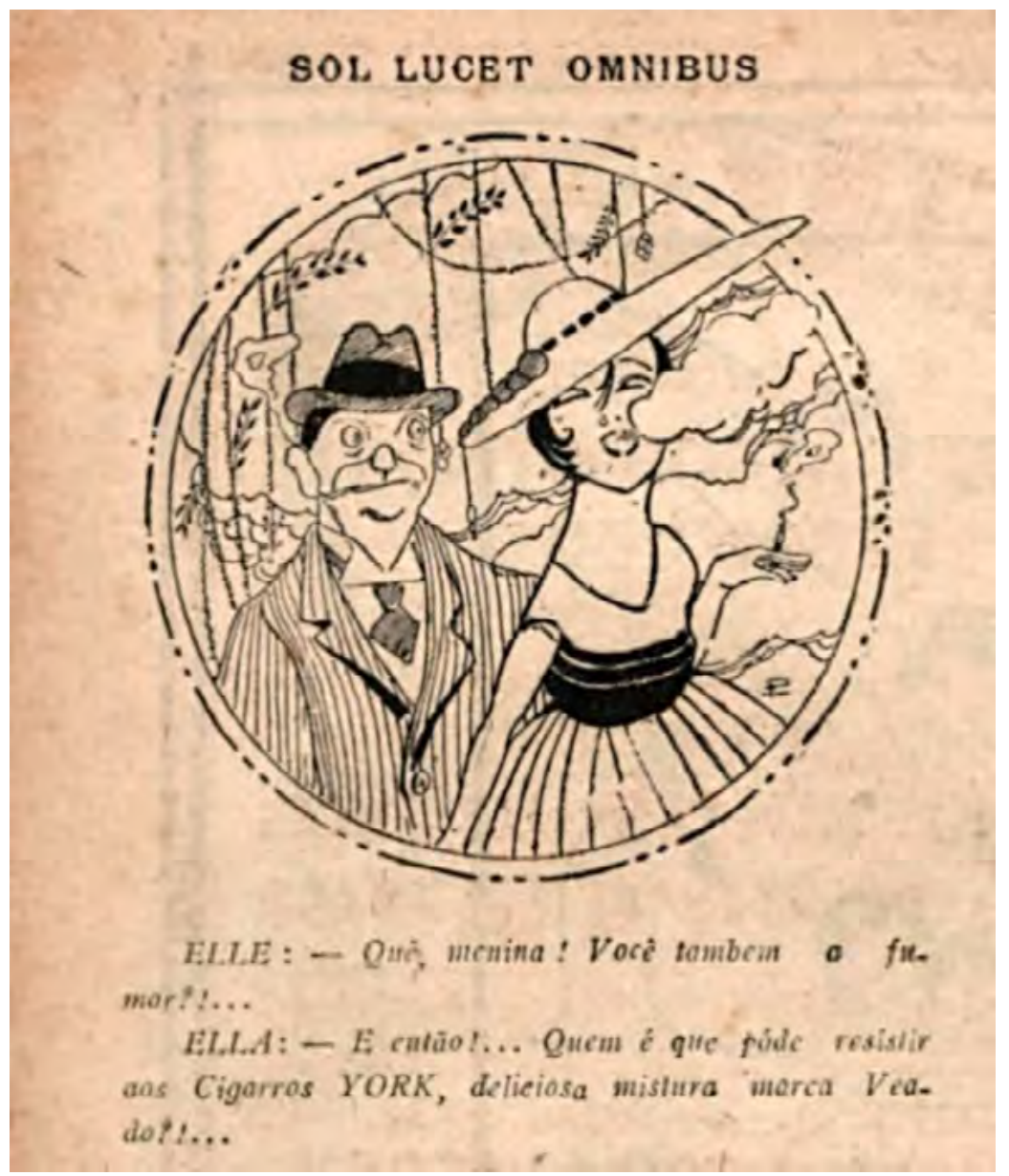

FONTE: O Malho, n. 811, 30 de março de 1919. Acervo particular.

"Ele: - Quê, menina! Você também a fumar?!...

Ela: - E então!... Quem é que pode resistir aos cigarros York, deliciosa mistura marca Veado?!..." (O MALHO, 1919, p. 7). 
Ao passo que o homem demonstra surpresa pela prática tabagista da senhorita, sublinhando a ideia de que não se tratava de algo corriqueiro, ela rebate com uma naturalidade justificada pelo apelo daquele prazer de consumo.

A presença da mulher em reclames de cigarro não era monopólio da fábrica Veado. A concorrente Companhia Souza Cruz, por exemplo, anunciava o cigarro Liberty em O Malho também utilizando uma mulher como protagonista. À medida que as mudanças de comportamento feminino se inscreviam no tecido social, o hábito de fumar passava a ser não apenas permitido, mas incorporado ao arquétipo de "mulher moderna". A moça que fuma na fotografia parece desfrutar da situação enquanto olha para algo - ou alguém - e sorri (figura12). Os cabelos curtos e os braços desnudos reforçam a ideia de uma persona em dia com hábitos indumentários modernos. Mas o comprimento e o volume da saia, somados ao gestual delicado das mãos, não traduzem uma noção de vulgaridade; do contrário, remetem a uma possível moça jovem e "antenada", que aproveitaria as vantagens do seu tempo para usufruir daquele prazer em página inteira. Não à toa, o nome do cigarro - Liberty - explicitamente clama por uma ideia de liberdade.

FIGURA 12 - CIGARROS "LIBERTY": O FUMO COMO EMBLEMA DA LIBERDADE FEMININA

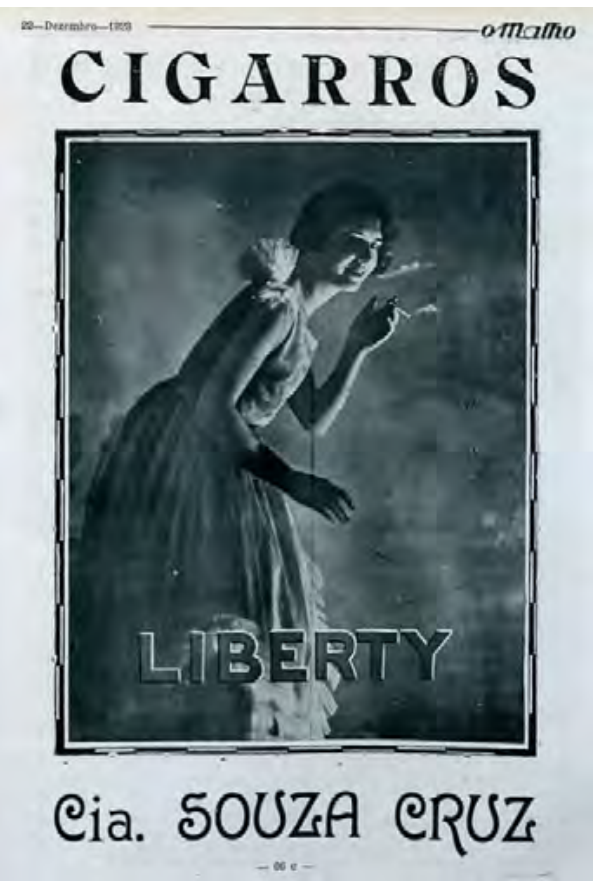

FONTE: O Malho, n. 373, 22 de dezembro de 1923. Acervo particular.

O novo hábito feminino estava presente em letra e imagem; no cinema, na literatura popular e nas revistas de variedade; em representações publicitárias, artísticas e gráfico-satíricas. 0 cartunista Belmonte - expoente da mesma geração de J. Carlos, extremamente renomado à sua época -, ofereceu retratos da "mulher que fuma" em seus cartuns. 0 conjunto humorístico do artista, publicado nas revistas cariocas Careta e Frou-Frou nos anos 1920, era inspirado pelo cotidiano da elite e da classe média em âmbito público e privado. Belmonte parecia interessado em registrar o modo como o ingresso brasileiro na modernidade se 
dava na prática cotidiana, ressaltando idiossincrasias e minúcias porventura verificadas na vivência de grupos que se identificavam como modernos.

Parte significativa de sua produção foi dedicada ao comportamento de mulheres na "babélica urbe", retratadas em situações desafiadoras, dispostas a afrontar antigos códigos de conduta. Ao registrar seus novos costumes, Belmonte destacou “o cigarro" por mais de uma vez em página inteira na Frou-Frou. Em uma das imagens, o tabagismo integrava a série "Atitudes femininas", conjunto de caricaturas publicadas de forma contígua que tratavam de hábitos audazes para velhos parâmetros. 0 cigarro figura como um acessório integrante do novo estatuto da mulher moderna, antes acessível prioritariamente para os homens.

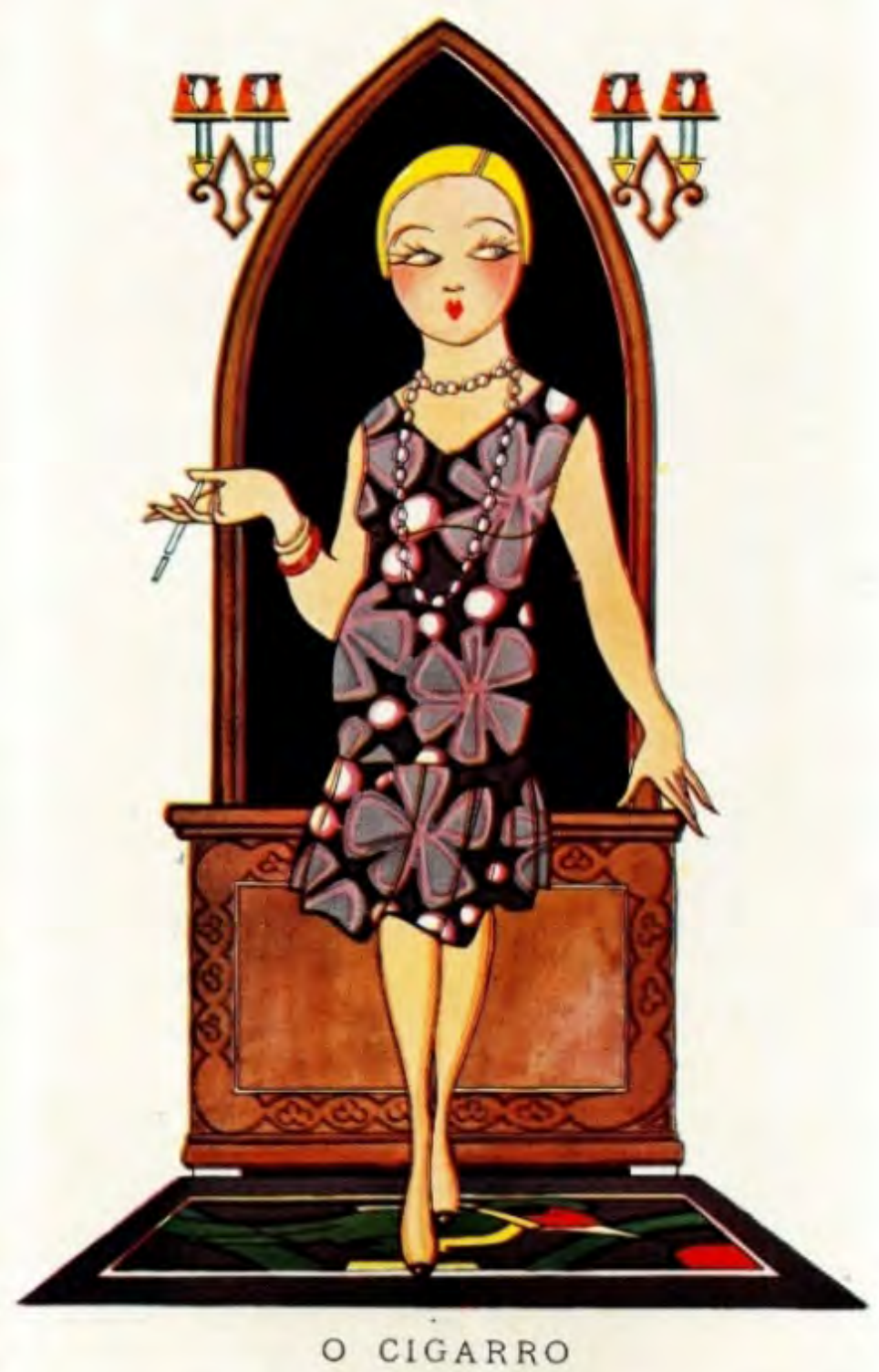

FONTE: Frou-Frou, n. 35, abril de 1926. Acervo particular. 
FIGURA 14: “O CIGARRO”, UMA DAS NOVAS ATITUDES FEMININAS DOS ANOS 1920

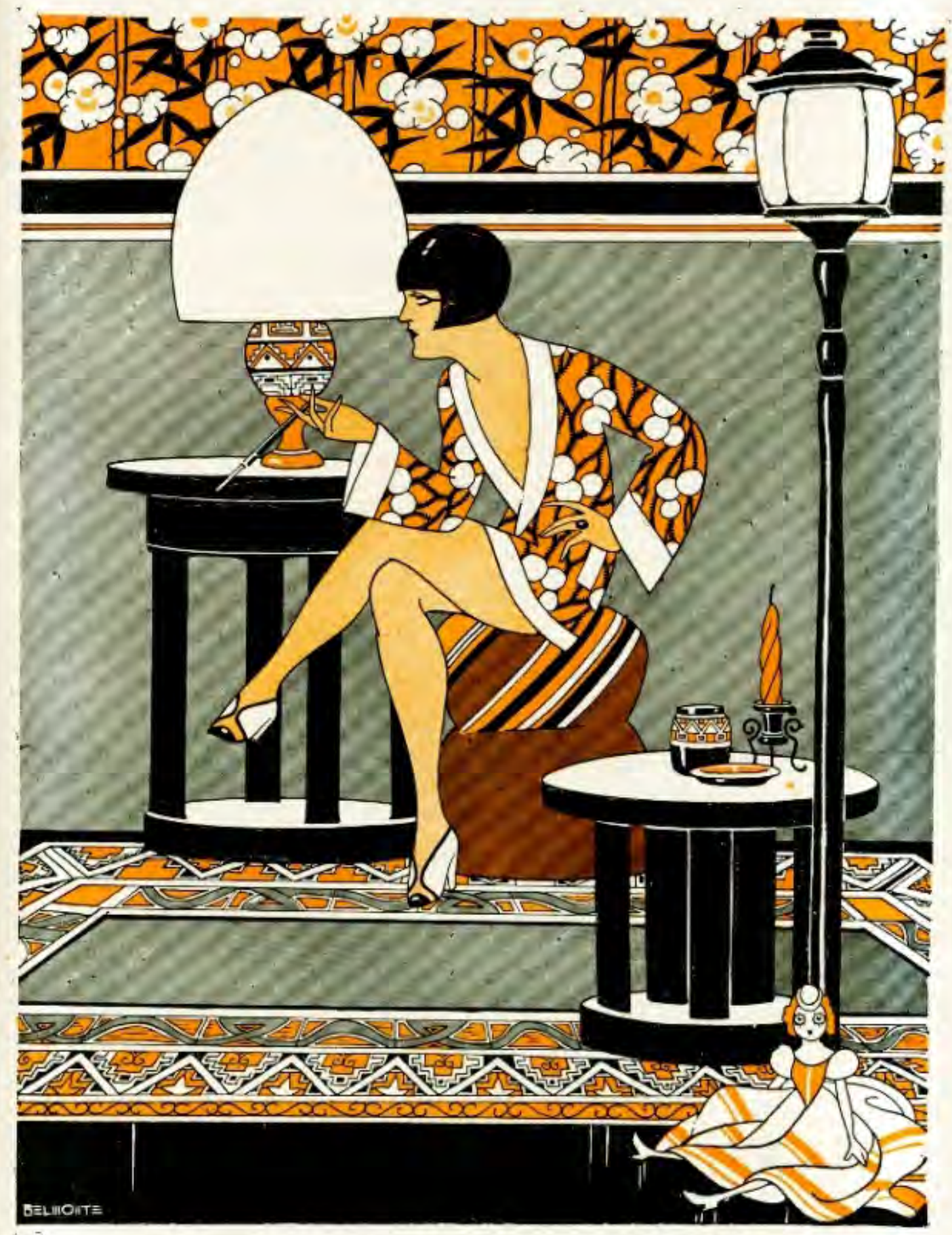

A T TITUDES FEMININAS

- cigarro

FONTE: Frou-Frou, n. 41, outubro de 1926. Acervo particular. 
Embora Freud afirmasse que "às vezes um charuto é apenas um charuto" (SHAPIR0, 2006, p. 292), não podemos deixar de pensar no cigarro como um elemento fálico, um objeto relacionado ao prazer, que passava a ser publicamente manuseado pelas mulheres, um insinuador de sua sexualidade. Nas representações anteriores, a erotização é evidente na postura corporal, no olhar, na roupa reveladora das mulheres e no próprio cigarro, que pontifica em meio a outros componentes sugestivos - a vela, por exemplo. 0 uso gráfico dos cenários explicita uma ambiência muito avant-garde a seu tempo (figura 15), casando o cigarro a novos arquétipos femininos.

Ao comparar a mulher de "ontem" e "hoje", Belmonte desenhou diferenças perceptíveis na composição da aparência feminina, alterações que, acreditamos, ultrapassavam a esfera estética e atingiam o campo da atuação.

\section{FIGURA 15 - A MULHER ONTEM E HOJE}
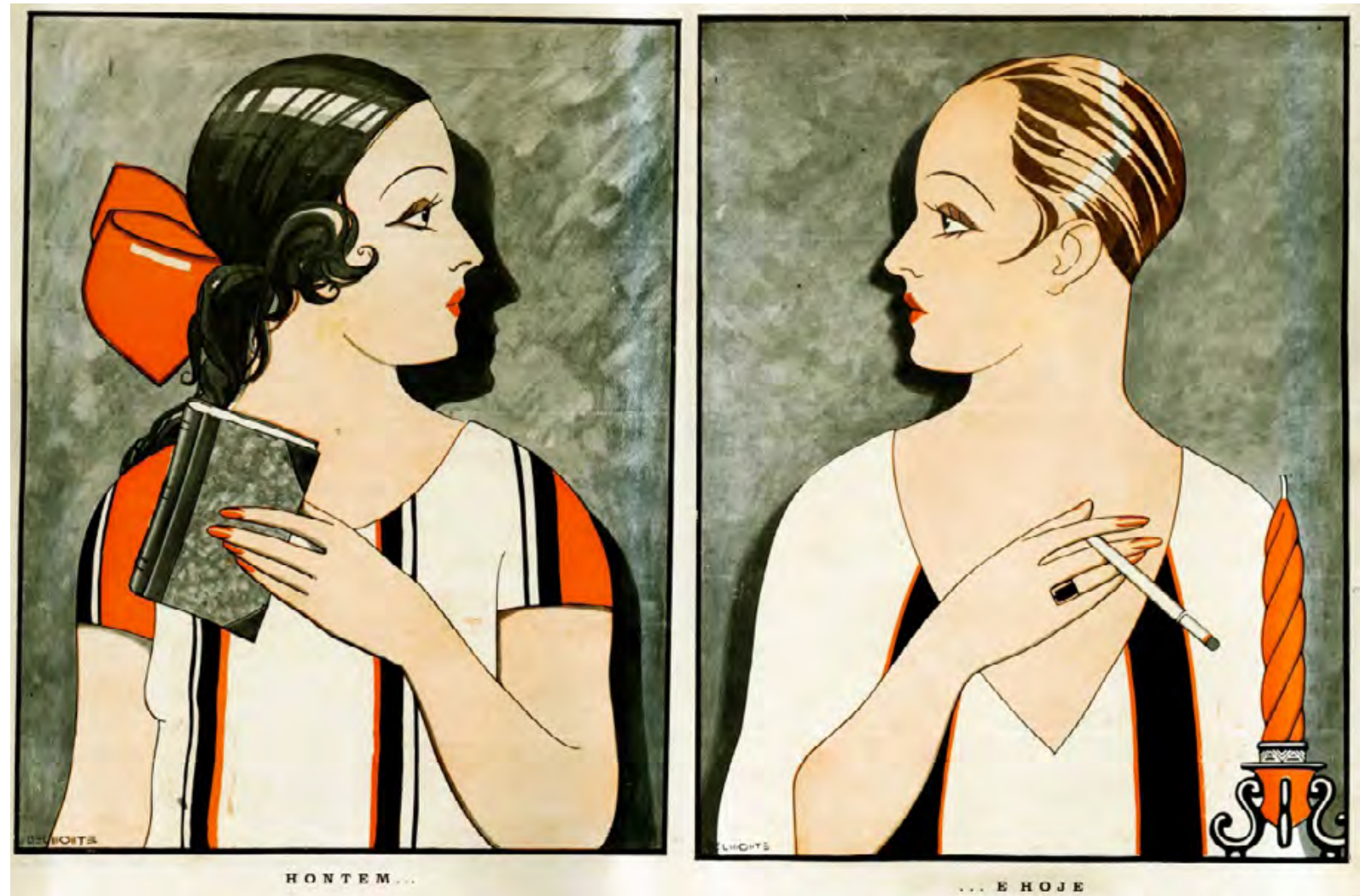

FONTE: Frou-Frou, n. 41, outubro de 1926. Acervo particular.

A "mulher de ontem" exalava romantismo e contenção no laço enorme que arrematava os longos cabelos, e levava às mãos um livro; um modelo confrontado frente a frente com seu "espelho inverso", i.e., a "mulher de hoje". Esta última, por sua vez, apresentava um visual andrógino com cabelos muito curtos, um decote bem mais avantajado, um anel geométrico que remetia a modelos masculinos art-déco e segurava entre os dedos uma piteira com o cigarro. Percebe-se, novamente, a inclusão de uma vela de formato fálico na constituição da cena na qual o objeto do fumo passava a compor um novo arranjo de designação de feminilidade. 
Muitas atribuições até então fortemente arraigadas às construções de gênero masculino e feminino começavam a cruzar balizas e embaçar limites; se na caricatura anterior Belmonte havia traçado sua versão para passado e presente, na próxima elaborou sua visão de "futuro" (figura 16), talvez um tempo não muito distante dali, quando duas mulheres masculinizadas, ou dois homens travestidos, poderiam acender o cigarro um(a) do(a) outro(a).

\section{FIGURA 16 - PREVISÕES DE NOVAS POSSIBILIDADES DE GÊNERO}

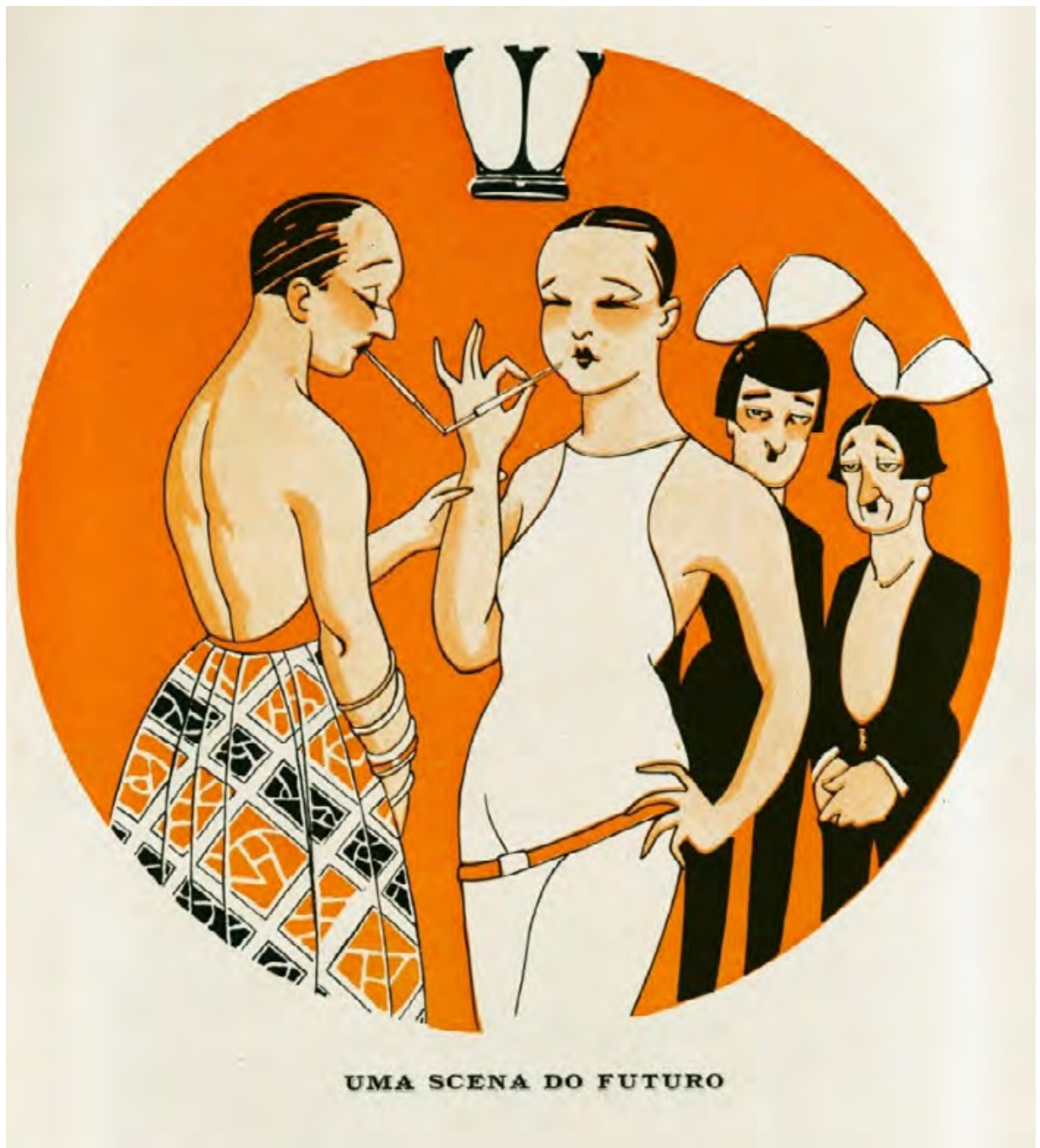

FONTE: Frou-Frou, n. 23, abril de 1925. Acervo particular.

A indefinição das identidades é acentuada nessa outra representação, de modo a provocar a dúvida no observador sobre os gêneros retratados: seriam homens ou mulheres? Se não era comum às mulheres fumar um cigarro, menos ainda duas mulheres acendê-lo em conjunto, em público; assim como não era usual dois homens com vestidos fazerem o mesmo em público. Acreditamos que a crítica de Belmonte fosse sobre o comportamento de mulheres que estariam "se masculinizando", mas não podemos deixar de vislumbrar, sobretudo à luz de uma leitura contemporânea, a possibilidade de serem dois homens vestidos de mulher. 
Com alta carga erótica, o gesto das piteiras que se tocam - e evocam dois lábios que se beijam - é acentuado pela postura nonchalant, pelos olhos semicerrados, pela mão que segura o braço, em uma demonstração de proximidade, carinho e intimidade; a indumentária, eminentemente feminina, apresenta corpos visíveis sob decotes profundos; e o cinto à direita direciona o olhar para a região pélvica, como uma faixa de "proibido" que cai frouxa sobre o vestido. Ao fundo, dois personagens com cabelo "Chanel" miram a cena, com olhar resignado, mãos contidas; estão vestidos com paletós (ou fraques estilizados), brincos e um enorme e extravagante laço no topo da cabeça, quase como "orelhas de burro" - seriam esses os homens do futuro, pasmos, efeminados e tolos perante a explosão da nova feminilidade?

Conforme já mencionado, a fruição pública do cigarro pelas mulheres naquele momento era alusiva à sua equiparação aos homens e seus direitos. E o gesto de acendê-lo em público por duas personagens com aproximações de gênero reapareceu na capa da revista americana Life do mês de agosto de 1925, na edição intitulada "Feminine number" (figura 17).

\section{FIGURA 17 - EQUIPARAÇÕES DE GÊNERO PERMEADAS PELO FUMO}

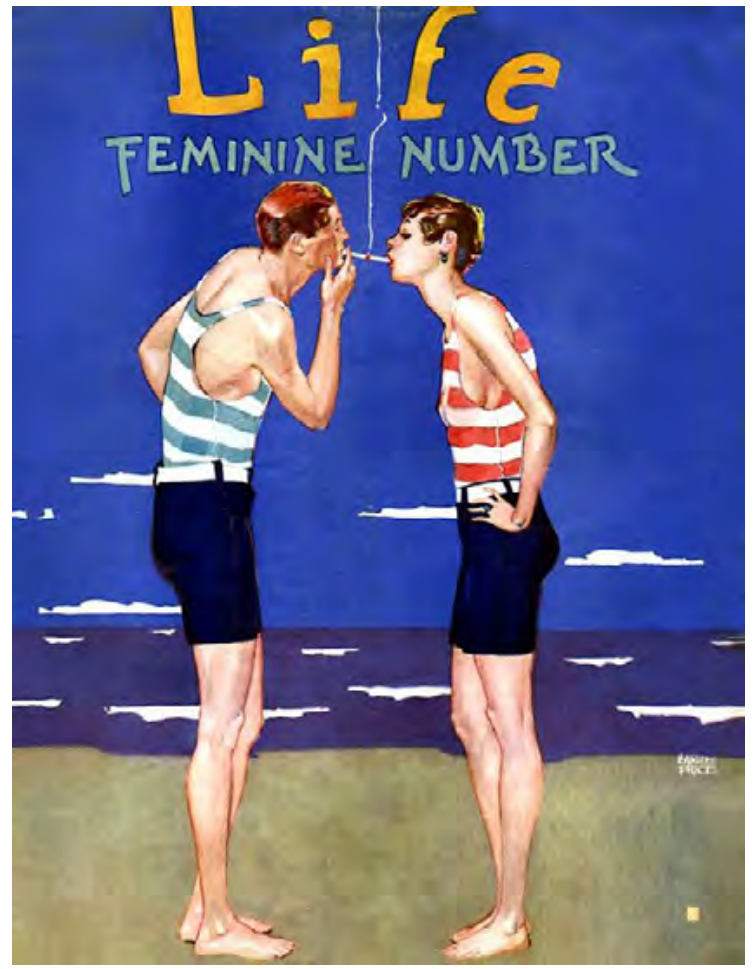

FONTE: Revista Life, agosto de 1925. Acervo particular.

Percebe-se que o autor da imagem utilizou elementos gráficos que de certa forma "igualavam" o homem e a mulher: as roupas de banho compostas por malha elástica, bermuda com cinto e os cabelos curtos emparelhavam os dois personagens independentemente do gênero. Sabemos que se tratava de homem e mulher pelo tipo físico, as feições e o brinco que ela usava, mas a indumentária denotava uma escolha andrógina capaz de sublinhar uma ideia de equiparação. E, finalmente, o cigarro aparecia "unindo" os dois atores em ignição mútua. 
Por meio de uma pesquisa comparada em revistas ilustradas de grande circulação, foi possível observar como as temáticas do tabagismo e do feminismo eram contempladas em franca conexão, quase simultaneamente em veículos publicados nos países centrais e no Brasil. Entre semelhanças e diferenças, foram evidenciadas novas atitudes que se inscreviam no cotidiano, inspiradas por informações circulantes em meios de comunicação globais. A vaga volumosa de comportamentos até então atípicos deflagrava toda sorte de reações; fosse para aprovação ou objeção, a perplexidade diante do novo arquétipo feminino era uma tônica comum.

Enquanto nos anos 1900-1910 prevaleceu nas revistas ilustradas a noção de "mulher elegante" fortemente referenciada às matrizes de moda e comportamento que emanavam da capital parisiense (GORBERG, 2013), nos anos 1920 somou-se àquele ideário a noção de "mulher moderna", balizada por novos parâmetros sugestionados pela cultura americana. Ela - "mulher moderna" - seria protagonista de atitudes e elaborações estéticas que incluiriam o cigarro como um de seus mais notórios indicadores.

Um sorriso para todas...

De linhas nítidas, retas, simples,

Mas estranhamente graciosas, ela

Realiza o tipo exato da beleza moderna - esquisita e diabólica.

As pupilas negras a dançar nas órbitas de olheiras artificiais,

Os dentes claros, que parecem um preconício de dentista americano,

A sorrir nos lábios vermelhos de "baton",

As pernas elásticas e longas a mover-se na graça exígua da saia curtíssima [...]

De manhã cedo, mal acorda, na carícia leve d'um quimono

Debruça-se na janela d'aquela pensão, para fumar tranquilamente a sua cigarette.

Tem um charme aquele cigarro n'aquela boca!...

E dentro da onda ligeira de fumo que a envolve,

Ela é um símbolo infinitamente expressivo da mulher moderna -

Que o efêmero fumo das paixões envolve e embeleza, embriaga e entontece...

(CARETA, n. 970, 22 jan. 1927, p. 34)

Eis as coisas que constituem o encanto maior da intimidade da mulher moderna: o pijama, as bonecas e as almofadas...

$[\cdots]$

E à hora tranquila do sonho [...], a mulher CHIC dentro do seu leve pijama de seda, com os cabelos cortados e o cigarro "Abdulla" nos lábios, lendo a sua última novela de amor, quer ser homem e é, mais do que nunca, mulher,

pois a fascinação do seu prestígio feminino cresce no disfarce dessas atitudes masculinas...

(CARETA, n. 971, 29 jan. 1927, p. 14) 
Juntamente com a adoção de visagismo e indumentária avant-garde - maquiagem, saia e cabelos curtos, pijama de seda -, o cigarro pontificava como objeto emblemático da "mulher moderna". Os editoriais apontavam seu uso como indicador do desejo feminino de equiparação de gênero - a mulher "quer ser homem" -, mas ratificavam o cigarro por outra razão: fumar contribuiria para o charme e a fascinação da mulher, percebida como alvo de sedução masculina.

Onipresentes nas ruas, nos salões, nas lojas, nos teatros, nos cinemas, nas praias, nas revistas, nos filmes, as mulheres passaram a ocupar como nunca um espaço real e representacional, figura em evidência no espaço da cidade e na subjetividade de seus habitantes. Acreditamos que, embora nas revistas e nos livros as mulheres se insurgissem sob nova roupagem, na prática estavam longe de conquistar uma irrestrita liberdade afetiva e financeira.

Por mais modernas que fossem, com ou sem cigarros, dificilmente elas corresponderiam à totalidade do estereótipo da melindrosa na práxis diária. Os mais tradicionalistas "torciam o nariz" para "mulheres que fumavam", temerosos pela decadência das novas gerações; mas, em que pese o temor pelo desmantelamento social, a família continuou a ser uma das mais eminentes bases estruturais da organização nacional, e as mulheres ainda teriam um longo percurso pela frente a ser desbravado na luta pela igualdade de direitos.

A partir da observação do hábito de fumar pelas mulheres no início do século XX, visamos flagrar vestígios de um processo de construção do feminino protagonizado por aquelas que ora desagradavam setores mais conservadores, ora inebriavam camadas mais permeáveis, sob enfoques que desautorizavam ou afirmavam experiências alternativas de subjetividade. 0 cigarro, aceso em um contexto mais amplo, é capaz de lançar luz sobre a desestabilização de antigas certezas masculinas e posicionamentos confortáveis para aqueles que, até então, eram senhores da situação nas relações de gênero.

\section{Referências}

Artigos em periódicos

A UMA melindrosa. Beira-Mar, n. 100, 23 jan. 1927, p. 12.

EIS AS coisas. Careta, n. 971, 29 jan.1927, p. 14.

MY lady's nicotine. Vogue, New York, v. 48, n. 12, dec. 15, 1916, p. 61.

O CIGARRO e as mulheres. Frou-Frou, n. 15, ago. 1924.

UM SORRISO para todas. Careta, n. 970, 22 jan. 1927, p. 34.

WALDRON, Ingrid. Patterns and causes of gender differences in smoking. Soc. Sci. Med., v. 32, n. 9, 1991, p. 989-1005. 


\section{Outras referências}

ABRAVANEL, Genevieve. Americanizing Britain: the rise of modernism in the age of the entertainment empire. Oxford: Oxford University Press, 2012.

ALLEN, Frederick Lewis. Only Yesterday: an informal history of the 1920's. Nova York: Perennial Classics, 2000, p. 95.

CAMELO DE ARAÚJO, Nelma, 2006, citado por FERNANDES, Backer Ribeiro. 0 mundo de Marlboro: a comunicação corporativa da Philip Morris Brasil. 2007. 177 f. Dissertação (Mestrado em Processo Comunicacionais) - Universidade Metodista de São Paulo, São Bernardo do Campo, 2007. Disponível em:

COSTALLAT, Benjamin. Paysagem sentimental. Rio de Janeiro: Ed. José Olympio, 1936, p. 161.

DEL PRIORE, Mary (org.). História das mulheres no Brasil. São Paulo: Ed. Contexto, 2004.

DROWNE, Kathleen; HUBER, Patrick. The 1920s: American Popular Culture Through History. Connecticut: Greenwood Publishing, 2004, p. 41.

FEIJÃO, Rosane. Moda e androginia nos anos 1920. In: XXVIII Simpósio Nacional de História, Florianópolis, 2015. Anais Anpuh. Disponível em: http://www.snh2015.anpuh. org/resources/anais/39/1434394828_ARQUIVO_Modaeandroginianosanos1920.pdf. Acesso em: 12 jun. 2018.

FEIJÃO, Rosane. Moda e modernidade na belle époque carioca. Rio de Janeiro: Estação das Letras e Cores, 2011.

GORBERG, Marissa. Parc Royal: um magazine na belle époque carioca. Rio de Janeiro: G. Ermakoff Casa Editorial, 2013.

GORBERG, Marissa. Um olhar sobre as caricaturas de Belmonte (1923-1927). 2018. Tese (Doutorado em História, Política e Bens Culturais) - CPDOC/FGV, Rio de Janeiro, 2018, p. 292-294. Disponível em: http://bibliotecadigital.fgv.br/dspace/handle/10438/20717. Acesso em: 22 jun. 2018.

HUGGINS, Mike. The Spectre of 'Americanisation': assessing the impact of America on British leisure between the wars. Disponível em: https://www.academia.edu/24648371/ The_Spectre_of_Americanisation_Assessing_the_impact_of_America_on_British_leisure_ between_the_wars. Acesso em: 22 jun. 2018. 
LATHAM, Angela. Posing a Threat: Flappers, Chorus Girls, and Other Brazen Performers of the American 1920s. Hanover, NH and London: Wesleyan University Press, 2000.

LE GOFF, Jacques; NORA, Pierre. História: novos problemas, novas abordagens, novos objetos. Rio de Janeiro: Francisco Alves, 1988, 3 v.

MARGUERITTE, Victor. La garçonne. Rio de Janeiro: Ed. Flamarion, 1922.

MARIANO, Olegário. Ba-Ta-Clan. Rio de Janeiro: Benjamin Costallat \& Miccolis Editores, 1927, p. 29.

PERROT, Michelle. Minha história das mulheres. São Paulo: Ed. Contexto, 2007.

PINHEIRO, Larissa Brum Leite Gusmão. Garçonnizando-se: o fazer-se melindrosa. Temporalidades, Belo Horizonte, ed. 17, v. 7, n. 2, maio/ago. 2015. Disponível em: https:// periodicos.ufmg.br/index.php/temporalidades/issue/view/307. Acesso em: 22 jun. 2018.

RESENDE, Beatriz (org.). Cocaína, literatura e outros companheiros de ilusão. Rio de Janeiro: Casa da Palavra, 2006, p. 17-18.

ROSS, Sara. The Hollywood Flapper. In: DESSER, David; JOWETT, Garth S. Hollywood Goes Shopping. Minnesota: University of Minnesota Press, 2000, p. 61.

SHAPIRO, Fred R. The Yale Book of Quotations. New Haven and London: Yale University Press, 2006, p. 292.

SODRÉ, Nelson Werneck. História da imprensa no Brasil. Rio de Janeiro: Mauad, 1999.

SOIHET, Rachel. Mulheres em busca de novos espaços e relações de gênero. Acervo - Revista do Arquivo Nacional. Rio de Janeiro, v. 9, n. 1-2, p. 99-105, jan./dez. 1996.

Disponível em: https://brapci.inf.br/index.php/res/download/54881. Acesso em: 26 jun. 2020.

ZEITZ, Joshua. A Madcap Story of Sex, Style, Celebrity and the Women Who Made America Modern. New York: Three Rivers Press, 2006.

\section{Agradecimentos}

À CAPES, pela concessão da bolsa sanduíche, e às organizadoras do Colóquio "Imprensa, Moda e Mulher" realizado na Fundação Casa de Rui Barbosa em agosto de 2018. 